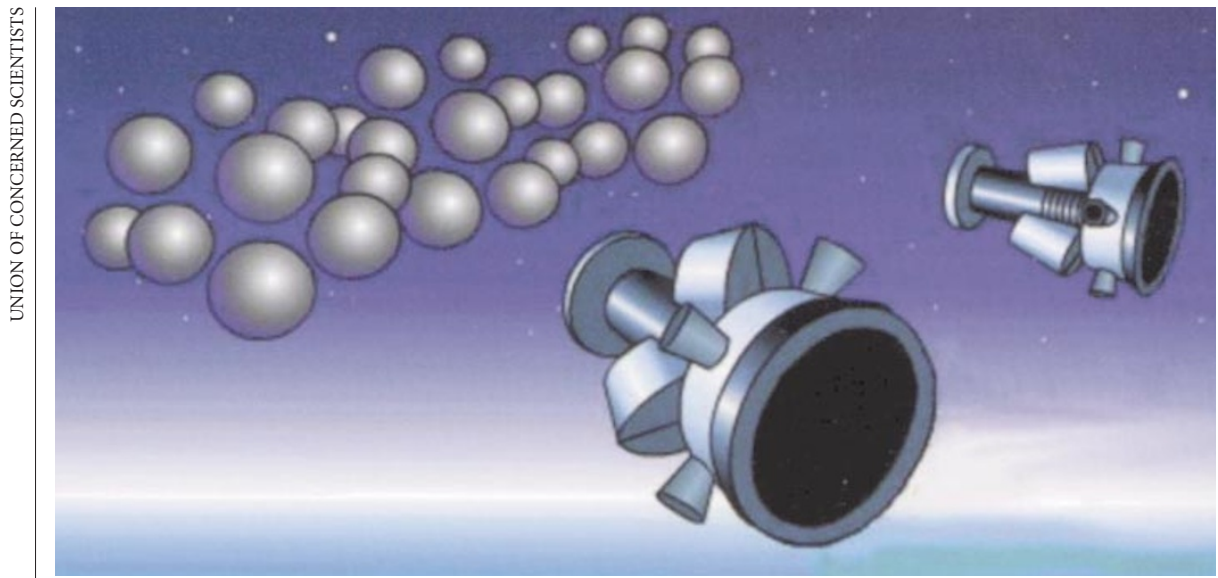

Shot down: nuclear warheads protected by decoy balloons (left) could confuse interceptors.

\title{
Critics blast US missile defence system as flawed
}

\section{Washington}

An independent group of senior physicists and engineers last week claimed that the $\$ 30$ billion US National Missile Defense system has a major flaw — it could easily be confused and penetrated by decoys.

Currently being developed by the Pentagon, the system is being billed as a means of defending the United States from nuclear, chemical or biological attack from so-called 'rogue' nations, such as Iraq or North Korea, which might build ballistic missiles.

But an assessment by the Union of Concerned Scientists and the security-studies programme at the Massachusetts Institute of Technology says that the system could be defeated by a ballistic missile that divides chemical warheads into bomblets, conceals its nuclear warheads in decoy balloons, or shields its payload with a liquid-nitrogencooled shroud.

The defence system, which depends on individual 'kill' vehicles to find and collide with incoming ballistic missiles before they re-enter the atmosphere, could therefore be overcome by fairly straightforward countermeasures.

"We assume that the whole system is deployed and that each of its components works," says Kurt Gottfried, one of the study's authors. "Even under those conditions it will not perform the job that it is expected to perform."

The panel's chairman, Andrew Sessler, a former director of the Lawrence Berkeley Laboratory in California, and former president of the American Physical Society, said that "the current National Missile Defense programme should be shelved as unworkable." He called on the Pentagon to have the programme reviewed by an external committee.

The panel says that decoy technology is simple to deploy and within the capability of any state that can develop a ballistic missile. A cooling shroud, for example, is likely to reduce the range at which a missile can be spotted by a factor of a thousand. A nuclear warhead inside a decoy balloon, the panel says, will travel at the same speed as an empty decoy balloon above the atmosphere, and will be indistinguishable from it.

The scientists hope their findings will encourage President Bill Clinton to defer a decision, due to be made this autumn, on whether to move towards deploying the system. The report was released the day before a Senate hearing on funding for the programme.

In an echo of 1980s debate about President Ronald Reagan's plan for a laser-based missile defence system, which became known as 'Star Wars', scientists are struggling to make their voice heard in what has become a highly politicized debate.

Clinton is under pressure to deploy the system in the run-up to November's congressional and presidential elections, in an effort to disarm Republican charges that Democrats are soft on defence.

A spokesman for the National Missile Defense office at the Pentagon said that the study's criticism was premature, and that the system would be able to deal with the threat of ballistic-missile attack by the time it became operational in 2005.

A decision to deploy the system would have important international ramifications, requiring the United States to withdraw from the Anti-Ballistic Missile (ABM) Treaty with the former Soviet Union, and raising questions about whether US allies would accommodate components of the system, or be protected by it.

Colin Macilwain http://www.ucsusa.org

\section{California targets GM-trial vandals with new legislation}

\section{San Francisco}

Troubled by vandalism at University of California research sites and elsewhere, a committee of the California state assembly has approved a bill that would create tough penalties for the destruction of research crops.

Under the proposed legislation, anyone who uprooted or harmed a crop under study would be liable for civil penalties of twice the value of the plants - including testing, research and development costs. Judges could also add on criminal sanctions.

Assemblywoman Helen Thomson (Democrat, Davis) introduced the legislation in response to a series of attacks carried out since last summer by anti-biotech activists. Protesters have destroyed corn, sugar beet, walnut trees, melons, tomatoes and equipment at sites belonging to the Davis and Berkeley campuses of the University of California.

Activists have also damaged sunflowers, corn, greenhouses and irrigation equipment belonging to the commercial companies Pioneer Hi-Bred and NK Seeds.

The protesters say they aim to sabotage research and cause economic damage. "If a research crop is 'nipped in the bud', so to speak, it may never make it to the commercial market," advises one instructional guide to anti-biotech sabotage posted on the Internet (see http://www.tao.ca/ ban).

Thomson told the legislators that the ruined studies could have helped to document the health and ecological effects of genetically modified crops. "Productive academic debate on the merits of genetically modified food products should be encouraged. Wanton destruction of another's property and research should not," she said.

Denny Henke, spokesman for a loose network of activist groups, rejects such complaints, arguing that GM crops are not being tested in any significant way before they enter the US marketplace. "The Food and Drug Administration and the Department of Agriculture seem to be acting as if these things are innocent until proven guilty," he says.

Henke adds that high fines probably would not deter the activists. However, no one at the hearing opposed the bill, which must be approved by the judiciary committee before being presented to the full assembly.

Sally Lehrmann 